\title{
Bioprocess Engineering Aspects of Biopolymer Production by the Cyanobacterium Spirulina Strain LEB 18
}

\author{
Roberta Guimarães Martins, Igor Severo Gonçalves, \\ Michele Greque de Morais, and Jorge Alberto Vieira Costa
}

\author{
Biochemical Engineering Laboratory, College of Chemistry and Food, Federal University of Rio Grande, Avenida Italia, \\ Km 8, P.O. Box 474, 96203-000 Rio Grande, RS, Brazil
}

Correspondence should be addressed to Jorge Alberto Vieira Costa; jorgealbertovc@terra.com.br

Received 19 August 2014; Revised 15 November 2014; Accepted 24 November 2014; Published 11 December 2014

Academic Editor: Saad Khan

Copyright (c) 2014 Roberta Guimarães Martins et al. This is an open access article distributed under the Creative Commons Attribution License, which permits unrestricted use, distribution, and reproduction in any medium, provided the original work is properly cited.

\begin{abstract}
Microbial biopolymers can replace environmentally damaging plastics derived from petrochemicals. We investigated biopolymer synthesis by the cyanobacterium Spirulina strain LEB 18. Autotrophic culture used unmodified Zarrouk medium or modified Zarrouk medium in which the $\mathrm{NaNO}_{3}$ content was reduced to $0.25 \mathrm{~g} \mathrm{~L}^{-1}$ and the $\mathrm{NaHCO}_{3}$ content reduced to $8.4 \mathrm{~g} \mathrm{~L}^{-1}$ or increased to $25.2 \mathrm{~g} \mathrm{~L}^{-1}$. Heterotrophic culture used modified Zarrouk medium containing $0.25 \mathrm{~g} \mathrm{~L}^{-1} \mathrm{NaNO}_{3}$ with the $\mathrm{NaHCO}_{3}$ replaced by $0.2 \mathrm{~g} \mathrm{~L}^{-1}, 0.4 \mathrm{~g} \mathrm{~L}^{-1}$, or $0.6 \mathrm{~g} \mathrm{~L}^{-1}$ of glucose $\left(\mathrm{C}_{6} \mathrm{H}_{12} \mathrm{O}_{6}\right)$ or sodium acetate $\left(\mathrm{CH}_{3} \mathrm{COONa}\right)$. Mixotrophic culture used modified Zarrouk medium containing $0.25 \mathrm{~g} \mathrm{~L}^{-1} \mathrm{NaNO}_{3}$ plus $16.8 \mathrm{~g} \mathrm{~L}^{-1} \mathrm{NaHCO}_{3}$ with the addition of $0.2 \mathrm{~g} \mathrm{~L}^{-1}, 0.4 \mathrm{~g} \mathrm{~L}^{-1}$, or $0.6 \mathrm{gL}^{-1}$ of glucose or sodium acetate. The highest biopolymer yield was $44 \%$ when LEB 18 was growing autotrophically in media containing $0.25 \mathrm{~g} \mathrm{~L}^{-1}$ $\mathrm{NaNO}_{3}$ and $8.4 \mathrm{~g} \mathrm{~L}^{-1} \mathrm{NaHCO}_{3}$.
\end{abstract}

\section{Introduction}

Instability in the international price of oil and natural gas, coupled with geopolitical factors and environmental concerns, has led to the need to substitute nonrenewable petroleum products with those based on renewable resources. The production of polymers from petrochemicals is the second major use of oil after their utilization as a source of energy [1]. Biopolymers can be produced using biofixation of carbon dioxide by cyanobacterium and could reduce both dependency on petroleum and carbon dioxide emissions [2].

Petrochemical-based plastics are resistant to degradation and most eventually end up in sanitary landfills, where they often compromise the circulation of gas and liquids and thus the decomposition of other materials within the site and may even make it unstable. Since landfill sites are becoming scarce, one solution is to substitute recalcitrant petrochemical-based plastics with biopolymers that do not cause such problems [3].
Polyhydroxyalkanoates (PHAs), including polyhydroxybutyrate (PHB), polyhydroxypropionate (PHP), and polyhydroxyvalerate (PHV), are bacterial or cyanophyte aliphatic polyesters which have thermoplastic, mechanical, and physical properties similar to polypropylene. PHAs are biocompatible, recyclable, and biodegradable and produce zero toxic waste since they biodegrade into carbon dioxide and water by microbial attack in about three months to one year $[4,5]$. These polymers have a high degree of polymerization and are crystalline, optically active, isotactic, and insoluble in water $[6,7]$.

Cyanobacteria have the potential for the production of biopolymers and their yield can be increased by stressing the culture via nutrient limitation or other means, use of recombinant strains [8], control of metabolic flux, and the use of different bioreactor types [1]. Some cyanophytes can adapt their metabolism during nutrient limitation [9], with biopolymer synthesis generally occurring when the carbon and energy source is present at normal levels or in 
excess while at least one other nutrient is limiting, nitrogen, phosphorus, magnesium, and iron being among the most common limiting nutrients [3]. Unlike crop plants, the cultivation of cyanobacteria does not require the use of large areas of ground and can occupy areas inappropriate for agriculture and thus does not compete with food production [10].

We investigated methods to stimulate the synthesis of biopolymer by the cyanophyte Spirulina strain LEB 18 cultivated with different carbon sources and reduced nitrogen levels.

\section{Material and Methods}

2.1. Microorganism and Culture Media. The cyanobacterium Spirulina strain LEB 18 [11] was maintained in unmodified Zarrouk liquid mineral salts medium, containing mineral salts $\left(\mathrm{K}_{2} \mathrm{HPO}_{4}, \mathrm{~K}_{2} \mathrm{SO}_{4}, \mathrm{NaCl}, \mathrm{MgSO}_{4}, \mathrm{CaCl}_{2}, \mathrm{FeSO}_{4}\right.$, and EDTA) and $16.8 \mathrm{~g} \mathrm{~L}^{-1}$ of sodium bicarbonate $\left(\mathrm{NaHCO}_{3}\right)$ as the carbon source and $2.5 \mathrm{~g} \mathrm{~L}^{-1}$ of sodium nitrate $\left(\mathrm{NaNO}_{3}\right)$ as the nitrogen source [12].

Autotrophic culture used unmodified Zarrouk medium or modified Zarrouk medium in which the $\mathrm{NaNO}_{3}$ content was reduced to $0.25 \mathrm{~g} \mathrm{~L}^{-1}$ and the $\mathrm{NaHCO}_{3}$ content was reduced to $8.4 \mathrm{~g} \mathrm{~L}^{-1}$ or increased to $25.2 \mathrm{~g} \mathrm{~L}^{-1}$. Heterotrophic culture used modified Zarrouk medium containing $0.25 \mathrm{~g} \mathrm{~L}^{-1} \mathrm{NaNO}_{3}$ with the $\mathrm{NaHCO}_{3}$ replaced by $0.2 \mathrm{~g} \mathrm{~L}^{-1}, 0.4 \mathrm{~g} \mathrm{~L}^{-1}$, or $0.6 \mathrm{~g} \mathrm{~L}^{-1}$ of glucose $\left(\mathrm{C}_{6} \mathrm{H}_{12} \mathrm{O}_{6}\right)$ or sodium acetate $\left(\mathrm{CH}_{3} \mathrm{COONa}\right)$. Mixotrophic culture used modified Zarrouk medium containing $0.25 \mathrm{~g} \mathrm{~L}^{-1} \mathrm{NaNO}_{3}$ plus $16.8 \mathrm{~g} \mathrm{~L}^{-1} \mathrm{NaHCO}_{3}$ with the addition of $0.2 \mathrm{~g} \mathrm{~L}^{-1}, 0.4 \mathrm{~g} \mathrm{~L}^{-1}$, or $0.6 \mathrm{~g} \mathrm{~L}^{-1}$ of glucose or sodium acetate. The growth media components are summarized in Table 1.

2.2. Experimental Conditions. Cultures were grown in $2 \mathrm{~L}$ closed photobioreactors with a working volume of $1.5 \mathrm{~L}$ and continuous agitation provided by the injection of sterile air. The inocula were adapted for 20 days in their respective culture media. The initial biomass concentration was $0.15 \mathrm{~g} \mathrm{~L}^{-1}$ and the initial volume was $1.5 \mathrm{~L}$. The cultures were maintained at $30^{\circ} \mathrm{C}$ for 15 days under a $12 \mathrm{~h}$ photoperiod and $3200 \mathrm{lux}$ provided by $40 \mathrm{~W}$ daylight-type fluorescent lamps.

2.3. Analytical Assays. Samples $(10 \mathrm{~mL})$ were collected aseptically at the same time every $24 \mathrm{~h}$ and the $\mathrm{pH}$ was measured at the same time using a $\mathrm{Q} 400 \mathrm{H}$ digital $\mathrm{pH}$ meter (Quimis, Brazil) according to the methodology of the Association of Analytical Communities [13]. Growth of LEB 18 was estimated by measuring the optical density at $670 \mathrm{~nm}$ in a Q798DRM spectrophotometer (Quimis, Brazil) and comparing the reading to a calibration curve relating optical density to biomass [14].

2.4. Determination of Kinetic Parameters. Growth curves of LEB 18 biomass against time were plotted and the following parameters calculated: maximum biomass concentration $\left(X_{\max }, \mathrm{g} \mathrm{L}^{-1}\right)$; productivity $\left(P, \mathrm{~g} \mathrm{~L}^{-1} \mathrm{~d}^{-1}\right)$, calculated as $P=$ $X_{t}-X_{0} / t-t_{0}[15]$, in which $X$ is the biomass $\left(\mathrm{g} \mathrm{L}^{-1}\right)$ at time $t$ (d) and $X_{0}$ is the biomass $\left(\mathrm{g} \mathrm{L}^{-1}\right)$ at time $t_{0}(\mathrm{~d})$, maximum productivity $\left(P_{\max }, \mathrm{g} \mathrm{L}^{-1} \mathrm{~d}^{-1}\right)$ being the productivity at $X_{\max }$, and specific growth rate $\left(\mu, \mathrm{d}^{-1}\right)$ was calculated as $\mu_{\max }=$ $0.693 / t_{d}$, where 0.693 is the natural logarithmic of 2 and $t_{d}$ is the biomass doubling time [16], the maximum specific growth rate being $\mu_{\max }\left(\mathrm{d}^{-1}\right)$.

2.5. Extraction Biopolymers. After fifteen days of cultivation, biopolymers were extracted from each photobioreactor run by centrifuging the culture media to precipitate the LEB 18 biomass, to which was added $10 \%$ to $12 \% \mathrm{v} / \mathrm{v}$ sodium hypochloride solution and the mixture recentrifuged. The supernatant was discarded and the precipitate was washed with distilled water, then recentrifuging and again discarding the supernatant and adding acetone to precipitate the biopolymer. Then, it was dried in an oven at $35^{\circ} \mathrm{C}$ for $48 \mathrm{~h}$.

The yield $(\eta)$ was calculated as grams of biopolymer (bp) per gram of biomass (bm) from the equation $\eta=m_{\mathrm{bp}} \times$ $100 / m_{\mathrm{bm}}$, where $m_{\mathrm{bp}}$ is the final amount of biopolymers in grams extracted from LEB 18 and $m_{\mathrm{bm}}$ is the amount of LEB 18 biomass in grams from which the biopolymers were extracted.

2.6. Statistics Analysis. Where appropriate, the data was subjected to analysis of variance (ANOVA) and the Tukey test at $P=95 \%$. All reagents were of at least analytical grade. Where appropriate, percentages are weight dry for weight dry $(\mathrm{w} / \mathrm{w})$ unless otherwise indicated.

\section{Results and Discussion}

The LEB 18 data is given in Table 1 and the growth curves are given in Figures 1 and 2, from which it can be seen that the different culture media were broadly similar regarding the various carbon sources (Table 1). The curves show no lag phase (Figures 1 and 2) because the inocula were preadapted for each culture medium, thus allowing LEB 18 to enter directly into the exponential growth phase. Growth, measured as $X_{\max }$, was not limited during the exponential phase, even in the experiments containing the maximum concentration of carbon $\left(16.8 \mathrm{~g} \mathrm{~L}^{-1}\right.$ of glucose or sodium acetate, $25.2 \mathrm{~g} \mathrm{~L}^{-1}$ of $\mathrm{NaHCO}_{3}$ ).

The culture which obtained the highest $X_{\max }$ value $\left(0.86 \mathrm{~g} \mathrm{~L}^{-1}\right)$ used $\mathrm{NaHCO}_{3}\left(8.4 \mathrm{~g} \mathrm{~L}^{-1}\right.$ and $\left.16.8 \mathrm{~g} \mathrm{~L}^{-1}\right)$ as the carbon source and $0.25 \mathrm{~g} \mathrm{~L}^{-1} \mathrm{NaNO}_{3}$ as the nitrogen source (Table 1 , Figure 2$)$. The highest $\mu_{\max }$ value $\left(0.12 \mathrm{~d}^{-1}\right)$ occurred with unmodified Zarrouk medium (Table 1). However, there was no statistical difference between any of the culture media regarding $X_{\max }$ values (Table 1 ). Since bicarbonate is the carbon source in unmodified Zarrouk medium, LEB 18 already expressed the enzymes necessary for carbon assimilation from this carbon source, enabling more growth than glucose or acetate.

The experiments were concluded after 15 days when the cultures entered the stationary phase. In general, the production of intracellular biocompounds generally occurs 


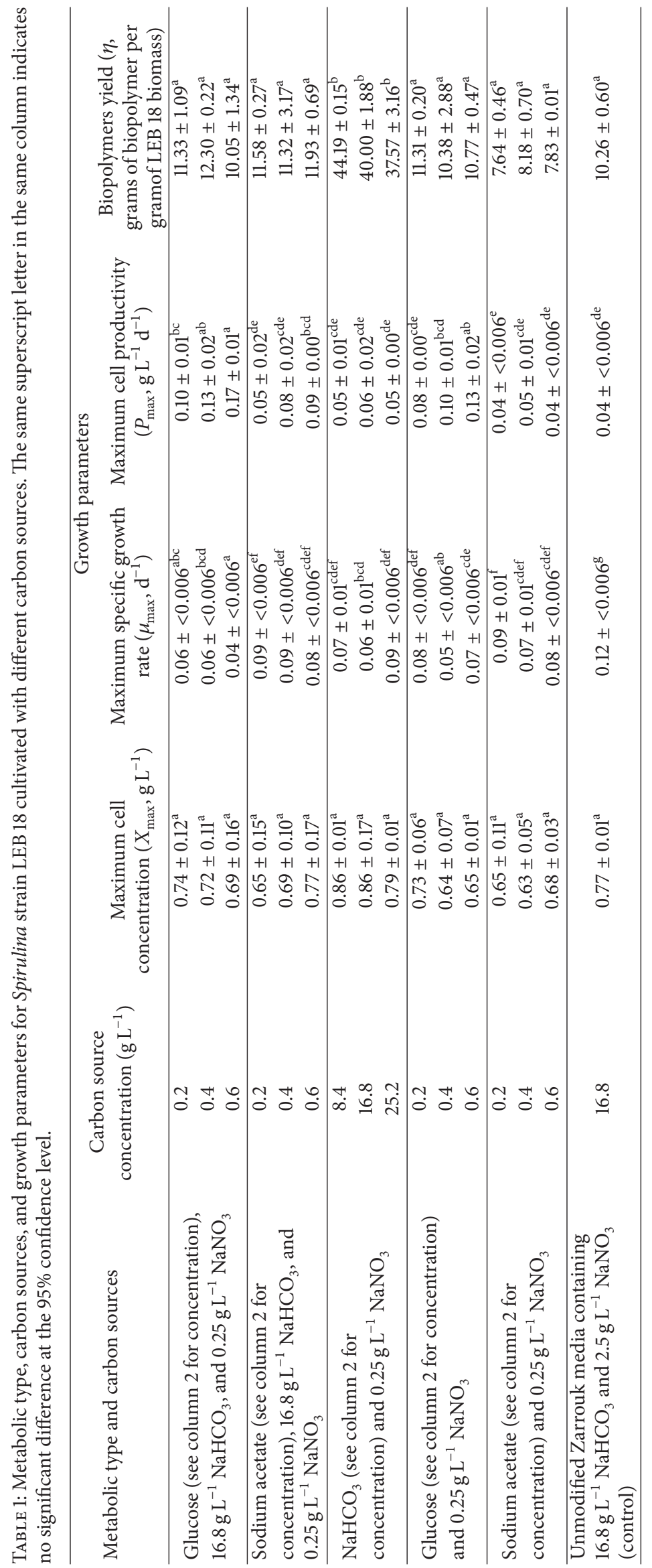




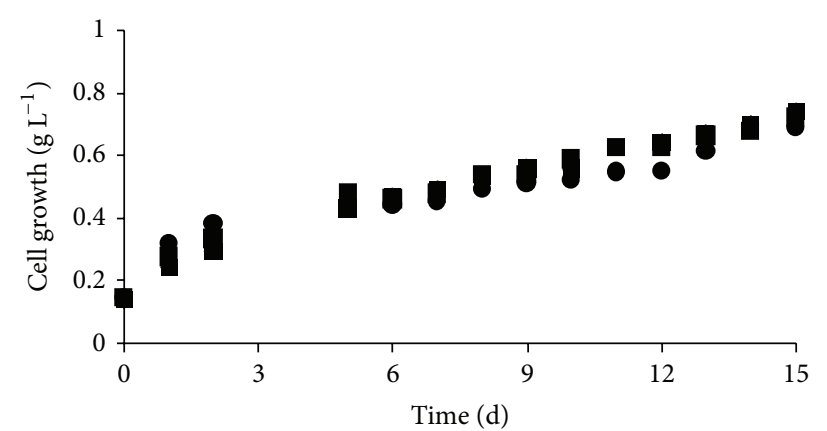

(a)

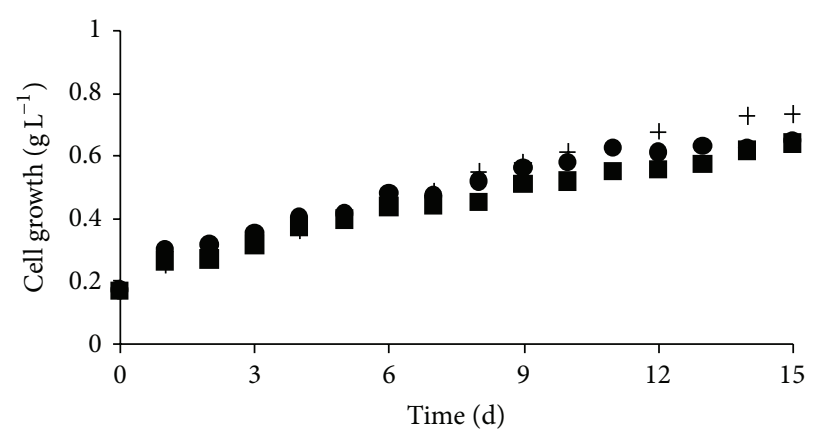

(c)

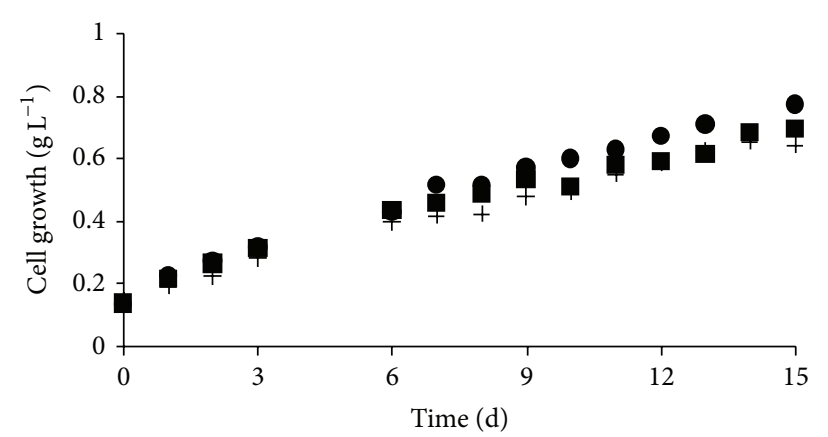

(b)

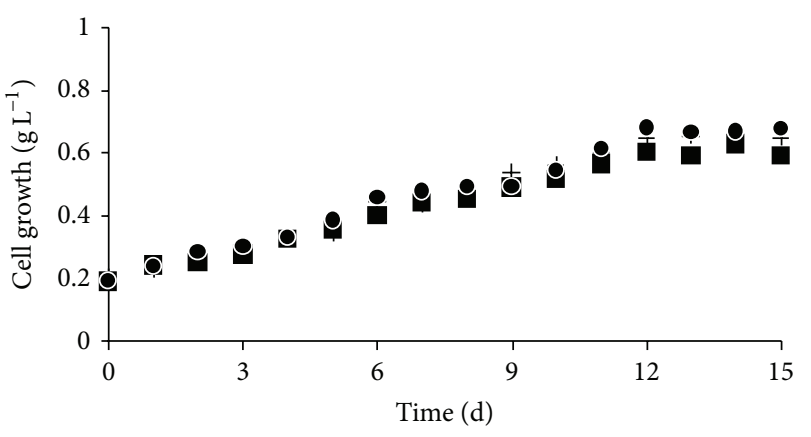

(d)

FIGURE 1: Growth curves for LEB 18 in modified Zarrouk media containing a reduced level of nitrogen $\left(0.25 \mathrm{~g} \mathrm{~L}^{-1} \mathrm{NaNO}_{3}\right)$ and the following carbon sources: (a) $16.8 \mathrm{~g} \mathrm{~L}^{-1} \mathrm{NaHCO}_{3}$ plus glucose, (b) $16.8 \mathrm{~g} \mathrm{~L}^{-1} \mathrm{NaHCO}_{3}$ plus sodium acetate, (c) glucose, and (d) sodium acetate. The glucose and acetate concentrations used were $0.2 \mathrm{gL}^{-1}(+), 0.4 \mathrm{gL}^{-1}(\varpi)$, and $0.6 \mathrm{~g} \mathrm{~L}^{-1}(\bullet)$.

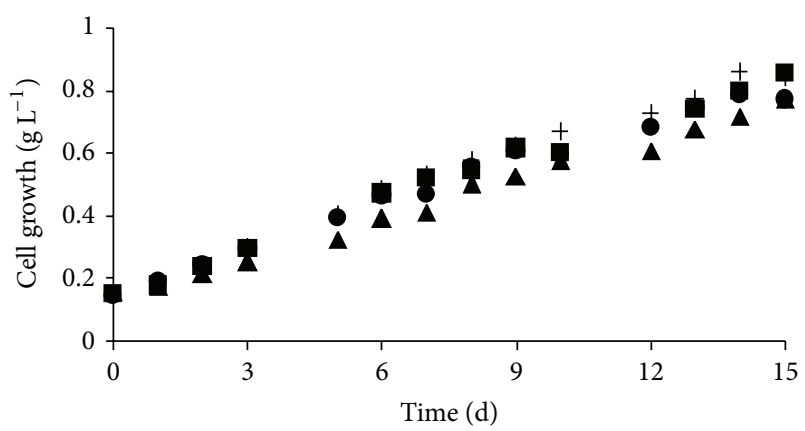

FIGURE 2: Growth curves for LEB 18 in modified Zarrouk media containing a reduced level of nitrogen $\left(0.25 \mathrm{~g} \mathrm{~L}^{-1} \mathrm{NaNO}_{3}\right)$ and $\mathrm{NaHCO}_{3}$ at the following concentrations: $8.4 \mathrm{~g} \mathrm{~L}^{-1}(+), 16.8 \mathrm{~g} \mathrm{~L}^{-1}(\mathbf{\square})$, and $25.2 \mathrm{~g} \mathrm{~L}^{-1}(\bullet)$. Results are also shown for unmodified Zarrouk medium containing $0.25 \mathrm{~g} \mathrm{~L}^{-1} \mathrm{NaNO}_{3}$ and $16.8 \mathrm{~g} \mathrm{~L}^{-1} \mathrm{NaHCO}_{3}(\boldsymbol{\Delta})$.

in the stationary phase when microbial growth ceases. However, biopolymers such as PHAs serve as intercellular energy reserves, because of which their production generally occurs during the exponential phase in parallel with whatever factor is used to measure cell growth, which in our case was the increase in LEB biomass. This aids in the survival of the producing microorganism, which can use PHAs for survival in the later stages of growth when nutrients become limiting.
We carried out preliminary tests in which we extracted biopolymers every 5 days for 30 days (data not shown) and observed that the end of the exponential phase and the beginning of the stationary phase occurred at around 15 days after inoculation and that biopolymer yields were highest at this time. Studies by other workers of biopolymer production by cyanophytes have shown higher yields during the stationary phase, with the cyanophyte Nostoc muscorum producing $8.6 \%$ [17] and the cyanophyte Synechocystis sp. strain PCC 6803 producing 45\% during this phase.

The quantity of nitrogen available is known to directly influence biopolymer synthesis and in our experiments the biopolymer yield increased fourfold from $10.26 \%$ to $40 \%$ when the sodium nitrate content was reduced from $2.5 \mathrm{~g} \mathrm{~L}^{-1}$ to $0.25 \mathrm{~g} \mathrm{~L}^{-1}, 10 \%$ of its original value (Table 1 ).

Unmodified Zarrouk medium contained $16.8 \mathrm{gL}^{-1}$ $\mathrm{NaHCO}_{3}$ plus $2.5 \mathrm{gL}^{-1} \mathrm{NaNO}_{3}$ and produced a yield $(\eta)$ of $10.26 \%$, probably due to the high level of nitrogen (Table 1). However, in modified Zarrouk media containing the same quantity of $\mathrm{NaHCO}_{3}$ but only $0.25 \mathrm{~g} \mathrm{~L}^{-1} \mathrm{NaNO}_{3}$ the biopolymer yield was $40 \%$. Furthermore, when growing in modified Zarrouk medium with reduced nitrogen, $\mu_{\max }=0.06 \mathrm{~d}^{-1}$ was half the rate occurring with unmodified Zarrouk medium, where $\mu_{\max }=0.12 \mathrm{~d}^{-1}$ (Table 1). It is known that $\mu_{\max }$ values are higher for actively growing cells, which was the case in unmodified Zarrouk medium, 
and that when energy is diverted for the synthesis of storage compounds, including biopolymers, lower values of $\mu_{\max }$ occur. It is interesting to note that while there was no statistically significant difference $(P>0.05)$ between the $\mu_{\max }$ values for the three versions of modified Zarrouk medium, there was a statistically significant difference $(P<0.05)$ between these and the unmodified Zarrouk medium (Table 1).

It has been reported that the eukaryotic algae Nannochloropsis growing in wastewater supplemented with $F / 2$ medium showed $\mu_{\max }=0.33 \mathrm{~d}^{-1}$ and a lipids content of $30 \%$ but when $\mu_{\max }=0.54 \mathrm{~d}^{-1}$ the lipid content was only $23 \%$ [18]. Other workers have reported $\mu_{\max }=0.13 \mathrm{~d}^{-1}$ during semicontinuous cultivation of the cyanophyte Cyanobium in BG-11 medium with the addition of $0.4 \mathrm{~g} \mathrm{~L}^{-1}$ of $\mathrm{NaHCO}_{3}$ [19].

The maximum productivity $\left(P_{\max }\right.$, Table 1$)$ occurred between the second and the eighth days of culture, probably because at this stage nutrients were available in greater concentrations and LEB 18 had been preadapted to the culture media (Figure 1(a)). Furthermore, during this initial period, little PHB would have been produced and the cultures energy resources could have been directed mainly to biomass production. In the trials with inorganic carbon, $P_{\max }$ occurred between the fifth and the eighth days of culture. Our $P_{\max }$ values ranged from $0.04 \mathrm{~g} \mathrm{~L}^{-1} \mathrm{~d}^{-1}$ to $0.17 \mathrm{~g} \mathrm{~L}^{-1} \mathrm{~d}^{-1}$ (Table 1), similar to the $P_{\max }=0.07 \mathrm{~g} \mathrm{~L}^{-1} \mathrm{~d}^{-1}$ reported for Cyanobium growing in BG-11 media [19] and $P_{\max }=0.08 \mathrm{~g} \mathrm{~L}^{-1} \mathrm{~d}^{-1}$ for LEB 18 growing in medium containing $10 \mathrm{~g} \mathrm{~L}^{-1} \mathrm{NaHCO}_{3}$ [2].

The medium which presented the highest biopolymer yield $(\eta)$ contained $8.4 \mathrm{gL}^{-1} \mathrm{NaHCO}_{3}$ and $0.25 \mathrm{gL}^{-1}$ of nitrogen, and there appeared to be a reduction in yield as the $\mathrm{NaHCO}_{3}$ concentration increased in the reduced nitrogen media, although the differences were not statistically significant (Table 1). However, it is known that although high levels of carbon are needed to stimulate the synthesis of biopolymers the excess can also inhibit production because although acetyl-CoA can enter the PHB biosynthesis pathway free acetyl-CoA inhibits the enzyme $\beta$-ketothiolase which is responsible for $\mathrm{PHB}$ synthesis.

The addition of the organic carbon sources, glucose, and sodium acetate did not stimulate either biomass production or biopolymer synthesis. Furthermore, there was no significant difference $(P<0.05)$ in biopolymer yield when adding sodium bicarbonate to cultures containing glucose or sodium acetate. It is known that when two endogenous carbon sources are available a microorganism usually gives preference to one of them. Since LEB 8 is generally maintained in unmodified Zarrouk medium containing sodium bicarbonate it already has the necessary pathways to utilize this nutrient, making two sources of carbon superfluous. It has been reported that Spirulina platensis UMACC 161 can produce $10 \%$ PHB when using a medium containing $9 \mathrm{~g} \mathrm{~L}^{-1}$ of $\mathrm{NaHCO}_{3}$ plus $0.5 \%$ sodium acetate without the presence of nitrogen but when the media contained $\mathrm{NaHCO}_{3}$ plus $\mathrm{CO}_{2}$ the PHB yield was around 3\% [20]. Yields of 47\% PHB have been reported for the cyanophyte Nostoc muscorum growing in BG-11 medium containing glucose and sodium acetate but without a nitrogen source [21].

The biopolymer poly(3-hydroxybutyrate-co-3-hydroxyvalerate) (PHBV) has been produced from Nostoc muscorum using various carbon sources (acetate, fructose, glucose, propionate, and valerate) with the PHBV yield being $28 \%$ when using $0.4 \% \mathrm{w} / \mathrm{v}$ acetate and $26 \%$ when using $0.4 \%$ $\mathrm{w} / \mathrm{v}$ glucose, the yield rising to $60 \%$ when the carbon source was $0.4 \%$ acetate or valerate and the nitrogen source was restricted [22]. Lower yields of 9.5\% have been reported for the cyanophyte Synechocystis sp. strain PCC 6803 growing in BG-11 medium. However, when cultivated with sodium acetate, the yield increased to $14.6 \%$ under nitrogen limitation and $25.7 \%$ under phosphate limitation [23].

The yield of microbial biopolymers is quite variable and depends on the composition of the medium used. When we grew LEB 18 on sodium bicarbonate, glucose, or sodium acetate along with different concentrations of nitrogen we obtained biopolymer yields varying from $7.64 \%$ to $44.19 \%$ (Table 1). The cyanophyte Aulosira fertilissima has been investigated for $\mathrm{PHB}$ production using media containing $0.2 \% \mathrm{w} / \mathrm{v}$ to $0.4 \% \mathrm{w} / \mathrm{v}$ acetate or citrate plus from zero to $20 \mathrm{mg} \mathrm{L}^{-1} \mathrm{~K}_{2} \mathrm{HPO}_{4}$ with an incubation period from 2 days to 14 days, with PHB yields ranging from $17 \%$ to $85.5 \%$ [24].

Bacteria produce large amounts of biopolymers in a short time; however, cyanobacteria have the advantage of using smaller amounts of nutrients due to photosynthesis, which uses the solar energy and transforms the carbon dioxide into oxygen, which is essential for humans.

Decreasing the quantity of nitrogen in the culture medium resulted in an increase in polymer production by LEB 18. Autotrophic growth in modified Zarrouk medium containing $16.8 \mathrm{~g} \mathrm{~L}^{-1}$ of $\mathrm{NaHCO}_{3}$ and $0.25 \mathrm{~g} \mathrm{~L}^{-1}$ of $\mathrm{NaNO}_{3}$ resulted in about $74 \%$ more biopolymer production than in unmodified Zarrouk medium (Table 1). It has been pointed out that cyanophyte Spirulina is a rich source of proteins [25], implying a large nitrogen requirement for growth. Under nitrogen limitation it is known that cyanophytes can divert carbon into other metabolic routes and produce biopolymers [21] to serve as carbon and energy storage compounds which can be reused when conditions become more favorable. The nitrogen content of the environment increases and the organism can produce proteins for cell growth rather than the storage lipids from which PHB derives.

\section{Conclusions}

In our experiments we found that the maximum biopolymer yield was $44.19 \%$ when LEB 18 was cultivated in modified Zarrouk medium containing $8.4 \mathrm{~g} \mathrm{~L}^{-1}$ of sodium bicarbonate and $0.25 \mathrm{~g} \mathrm{~L}^{-1}$ of sodium nitrate. The biopolymers produced by cyanobacteria have many uses because they present biocompatibility with mammalian cells and tissues and biodegradability. The main applications for biopolymers are in the food and medical areas, but they can also help reduce the environmental pollution generated by petrochemicalderived plastics. 
This study shows that the cyanobacteria are potential sources of biopolymers, because they can use smaller amounts of nutrients and help to reduce the environmental pollution.

\section{Conflict of Interests}

The authors declare that there is no conflict of interests regarding the publication of this paper.

\section{References}

[1] L. F. Silva, J. G. C. Gómez, R. C. S. Rocha, M. K. Tacino, and J. G. C. Pradella, "Produção biotecnológica de poli-hidroxialcanoatos para a geração de polímeros biodegradáveis no Brasil," Química Nova, vol. 30, no. 7, pp. 1732-1743, 2007.

[2] M. R. Andrade, F. V. Camerini, and J. A. V. Costa, "Perda química de carbono e cinética do crescimento celular em cultivos de Spirulina," Química Nova, vol. 31, no. 8, pp. 2031-2034, 2008.

[3] U. A. Lima, E. Aquarone, W. Borzani, and W. Schmidell, Biotecnologia Industrial-Processos Fermentativos e Enzimáticos, vol. 3, Edgard Blücher, São Paulo, Brazil, 2001.

[4] V. A. Konagesli Jr., L. Dagostini, and M. Renz, Plásticos Biodegradáveis: Revisão Sobre Métodos de Preparação e Propriedades da Biodegradação, Departamento de Biologia e Química, Universidade Regional do Noroeste do Estado do Rio Grande do Sul, 2012, http://www.scribd.com/doc/3033642/PLASTICOSBIODEGRADAVEIS.

[5] H. Abe and Y. Doi, "Structural effects on enzymatic degradabilities for poly[(R)-3-hydroxybutyric acid] and its copolymers," International Journal of Biological Macromolecules, vol. 25, no. 1-3, pp. 185-192, 1999.

[6] D. B. Hazer, E. Kiliçay, and B. Hazer, "Poly(3-hydroxyalkanoate)s: diversification and biomedical applications: a state of the art review," Materials Science and Engineering C, vol. 32, no. 4, pp. 637-647, 2012.

[7] C. S. K. Reddy, R. Ghai, and V. C. Kalia, "Polyhydroxyalkanoates: an overview," Bioresource Technology, vol. 87, no. 2, pp. 137-146, 2003.

[8] A. Shrivastav and S. K. Mishra, "Polyhydroxyalkanoate (PHA) synthesis by Spirulina subsalsa from Gujarat coast of India," International Journal of Biological Macromolecules, vol. 46, no. 2, pp. 255-260, 2010.

[9] T. M. Mata, A. A. Martins, and N. S. Caetano, "Microalgae for biodiesel production and other applications: a review," Renewable and Sustainable Energy Reviews, vol. 14, no. 1, pp. 217-232, 2010.

[10] S. Nonhebel, "Renewable energy and food supply: will there be enough land?" Renewable and Sustainable Energy Reviews, vol. 9, no. 2, pp. 191-201, 2005.

[11] M. G. Morais, C. D. Reichert, F. Dalcanton, A. J. Durante, L. F. Marins, and J. A. V. Costa, "Isolation and characterization of a new Arthrosphira strain," Zeitschrift für Naturforschung C, vol. 63, no. 1-2, pp. 144-150, 2008.

[12] C. Zarrouk, Contribution à l'étude d'une Cyanophycée, influence de diveurs facteurs physiques et chimiques sur la croissance et photosynthese de Spirulina maxima Geitler [Ph.D. thesis], University of Paris, Paris, France, 1966.

[13] AOAC, Official Methods of Analysis, Method 923.05, chapter 32, Supplement, 15, Association of Analytical Communities, 1995.
[14] J. A. V. Costa, M. G. De Morais, F. Dalcanton, C. Da Cruz Reichert, and A. J. Durante, "Simultaneous cultivation of Spirulina platensis and the toxigenic cyanobacteria Microcystis aeruginosa," Zeitschrift fur Naturforschung C: Journal of Biosciences, vol. 61, no. 1-2, pp. 105-110, 2006.

[15] J. E. Bailey and D. F. Ollis, Biochemical Engineering Fundamentals, McGraw-Hill, Singapore, 2nd edition, 1986.

[16] W. Schmidell, A. U. Lima, E. Aquarone, and W. Borzani, Biotecnologia Industrial, vol. 2, Edgard Blücher, São Paulo, Brazil, 2001.

[17] L. Sharma and N. Mallick, "Accumulation of poly- $\beta$-hydroxybutyrate in Nostoc muscorum: regulation by $\mathrm{pH}$, light-dark cycles, N and P status and carbon sources," Bioresource Technology, vol. 96, no. 11, pp. 1304-1310, 2005.

[18] L. Jiang, S. Luo, X. Fan, Z. Yang, and R. Guo, "Biomass and lipid production of marine microalgae using municipal wastewater and high concentration of $\mathrm{CO}_{2}$," Applied Energy, vol. 88, no. 10, pp. 3336-3341, 2011.

[19] A. A. Henrard, M. G. de Morais, and J. A. V. Costa, "Vertical tubular photobioreactor for semicontinuous culture of Cyanobium sp," Bioresource Technology, vol. 102, no. 7, pp. 4897-4900, 2011.

[20] M.-H. Jau, S.-P. Yew, P. S. Y. Toh et al., "Biosynthesis and mobilization of poly(3-hydroxybutyrate) $[\mathrm{P}(3 \mathrm{HB})]$ by Spirulina platensis," International Journal of Biological Macromolecules, vol. 36, no. 3, pp. 144-151, 2005.

[21] L. Sharma, A. Kumar Singh, B. Panda, and N. Mallick, "Process optimization for poly- $\beta$-hydroxybutyrate production in a nitrogen fixing cyanobacterium, Nostoc muscorum using response surface methodology," Bioresource Technology, vol. 98, no. 5, pp. 987-993, 2007.

[22] R. Bhati and N. Mallick, "Production and characterization of poly(3-hydroxybutyrate-co-3-hydroxyvalerate) co-polymer by a $\mathrm{N}_{2}$-fixing cyanobacterium, Nostoc muscorum Agardh," Journal of Chemical Technology and Biotechnology, vol. 87, no. 4, pp. 505-512, 2012.

[23] B. Panda, P. Jain, L. Sharma, and N. Mallick, "Optimization of cultural and nutritional conditions for accumulation of poly$\beta$-hydroxybutyrate in Synechocystis sp. PCC 6803," Bioresource Technology, vol. 97, no. 11, pp. 1296-1301, 2006.

[24] S. Samantaray and N. Mallick, "Production and characterization of poly- $\beta$-hydroxybutyrate (PHB) polymer from Aulosira fertilissima," Journal of Applied Phycology, vol. 24, no. 4, pp. 803814, 2012.

[25] K. H. Ogbonda, R. E. Aminigo, and G. O. Abu, "Influence of temperature and $\mathrm{pH}$ on biomass production and protein biosynthesis in a putative Spirulina sp," Bioresource Technology, vol. 98, no. 11, pp. 2207-2211, 2007. 

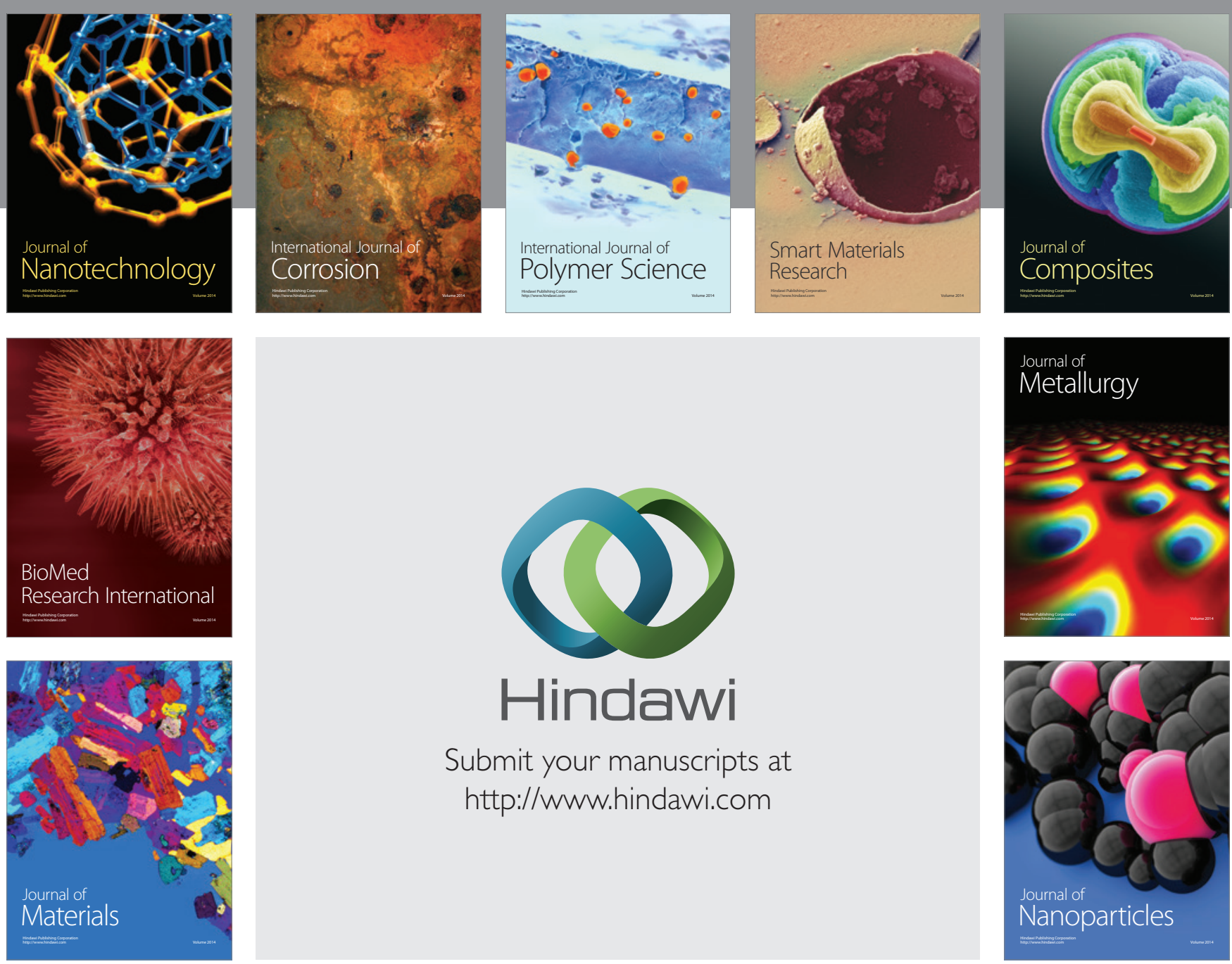

Submit your manuscripts at http://www.hindawi.com
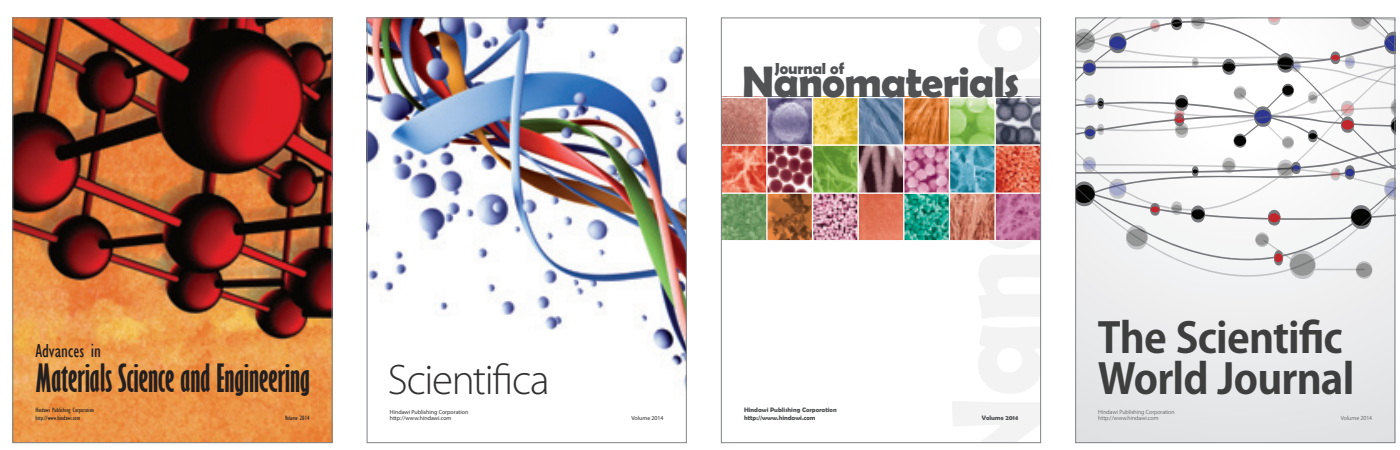

\section{The Scientific World Journal}
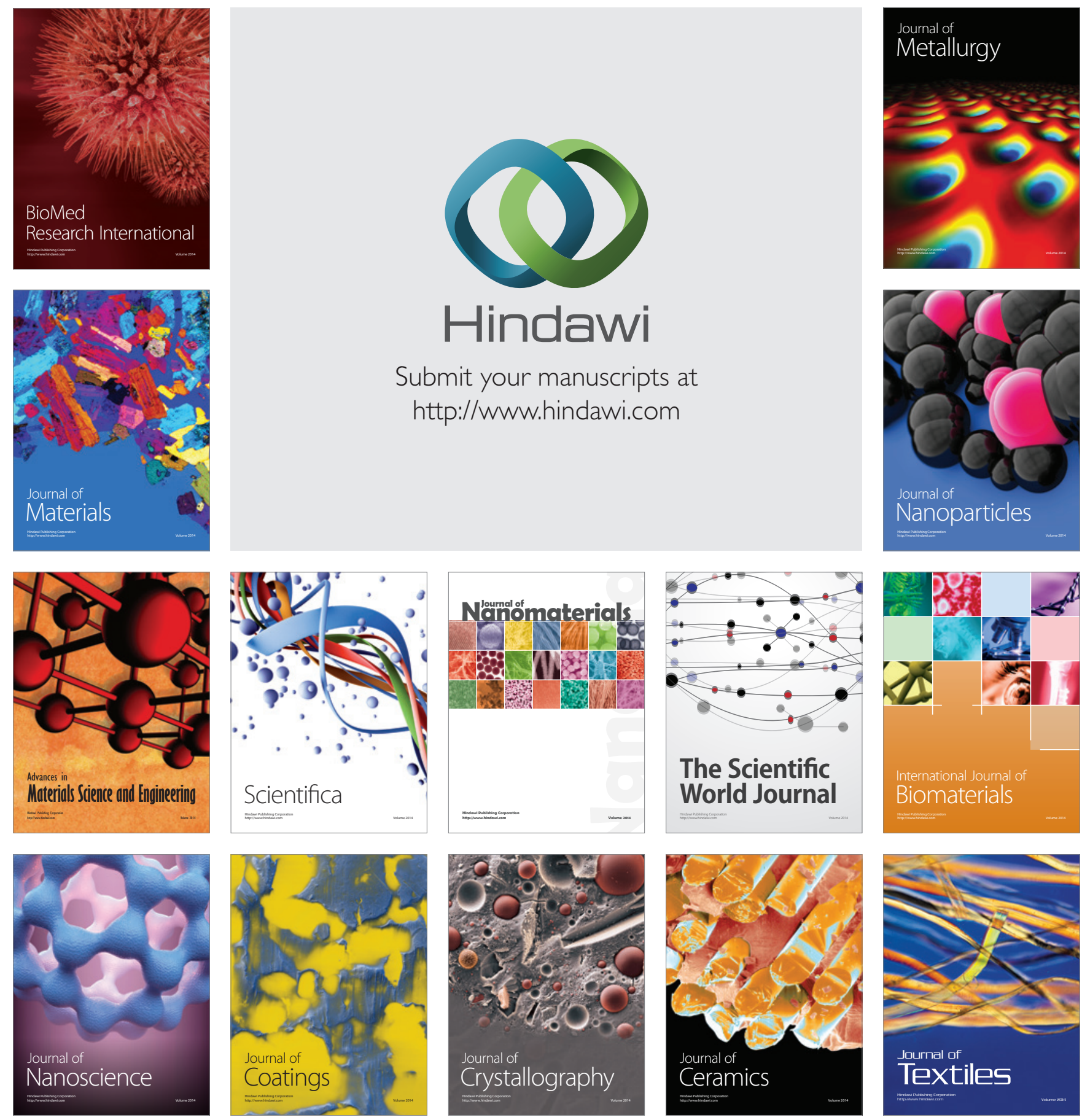